\title{
Yararsız Tedavi
}

\section{Futille Treatment}

\author{
H. Volkan Acar
}

Özet: Kesin bir tanım yapmak zor olsa da, yararsız tedavi (ya da nafile, boşuna, beyhude tedavi) için, “yararlı bir amaca hizmet etmeyen, tümüyle etkisiz tedaviler” şeklinde bir açıklama getirilebilir. Yararsız tedavi kapsamında ortaya çıkan sorunların çözümü için, iki farklı yaklaşım önerilmektedir. Bu amaçla, ya tedaviyi sonlandırma ya da tedaviyi başlatmama için gereken ölçütler oluşturulur, ya da mevcut sorunların çözümüne yönelik süreçler üzerine odaklanılır. Sorunun çözümünde en önemli aşamalardan birisi ise, kurumsal politikaların oluşturulmasıdır. Bu tür politikalar hasta, hasta yakınlar, hekimler ve kurumlarm katılımını sağlamal, ayrıca sürece etik danısmanlık ve etik kurullar gibi yapıları dahil etmelidir.

Anabtar Kelimeler: Yararsiz tedavi, Etik kurullar, Kurumsal politika

$-$

Abstract: Although it is difficult to make a clear definition of futile treatment, it can be explained as "serving no useful purpose, completely ineffective treatments". Two different approaches are suggested to solve the problems related with futile treatment. Either it is formed criteria for withholding or withdrawing treatment or it is focused on the processes toward solving of present problems. One of the important steps of solving problem is to form instutional policies. These kind of policies should provide the participation of patient, surragetes, physicians and instutions as well as should incorporate the systems such as ethical consultation and ethics committees to this process.

Keywords: Futile treatment, Ethics committees, Institutional policy

\section{Giriş}

Tıpta son 50-60 yılda yaşanan büyük ilerlemeler sayesinde artık hem tanıda hem de tedavide, önceki dönemlere kıyasla çok sayıda yeni seçenek ortaya çıkmış durumdadır. Tedaviyle ilgili seçeneklerin artmış olması, ilgili uzmanlık alanı dışında başka alanları da etkilemeye başlamıştır. Bu bağlamda tıp etiği de bu değişikliklerden etkilenmiş ve yeni anlayışlar geliştirmek durumunda kalmıştır. Bu yeni anlayışın bir yansıması olarak, yararcıllğın merkezde olduğu bir etik anlayıştan, özerkliğin ön planda olduğu bir etik anlayışa geçilmiştir. Yani artık hekim, hasta adına ve hastanın en yüksek çıkarlarını gözeterek karar vermemekte, eldeki seçenekleri hastaya sunup son kararı hastanın vermesini beklemektedir.

$\mathrm{Bu}$ yazının içeriğini oluşturan ve yararsız tedavi (faydasız tedavi, boşuna tedavi ya da tıbbi yararsızlık) olarak adlandırılan konu da, bu kapsamda ele alınan başlıklar arasında yer almaktadır.

\section{Tanım}

Yararsız tedavi konusu tartışılırken, tanımın doğru ve kapsayıcı bir şekilde yapılması önemlidir. Çünkü bu sayede uygulamada ortaya çıkabilecek birçok sorunun önüne baştan geçilmiş olur.

aDoç. Dr., Ankara Eğitim ve Araştırma Hastanesi Anestezi Kliniği, Ankara $₫$ hvacar@yahoo.com

Gönderim Tarihi: $12.09 .2016 \bullet$ Kabul Tarihi: 24.10.2016 
Konuyla ilgili kaynaklarda sıkça kullanılan İngilizce futile sözcügü sözlüklerde, "yararlı bir amaca hizmet etmeyen, tümüyle etkisiz” olarak açıklanmaktadır (1). Türkçe kaynaklarda futile sözcüğünün karşılığı olarak nafile (2-4), beyhude (5), boşuna $(6,7)$ ya da yararsız $(6,8)$ gibi sözcüklerin kullanıldığı görülmektedir. Biyoetik Terimleri Sözlüğü’nde futility karşılığı olarak "boşunalık", futile treatment karşıl lğ̆ olarak da "boşuna tedavi" ve "yararsız sağaltım" karşlıkları bulunmaktadır (6).

İngilizcedeki futile sözcüğünü karşılamak için, Türkçede tek bir sözcük üzerinde görüş birliği sağlanamamış olması yanında, sözcüğün neyi ifade ettiği yani tanımı konusunda da bir yetersizlik olduğu dikkat çekmektedir. Ülkemizde yoğun bakım hemşireleri üzerinde yapılan bir çalışmada, hemşirelerin 1/3’ünden fazlasının yararsız tedavi ve uygulamanın tanımını yapamadıkları saptanmıştır (8).

Konuyla ilgili yayınlar incelendiğinde, yakın zamanda yararsız tedavi (futile treatment) yerine artık daha çok tıbbi yararsızlık (medical futility) ifadesinin ön plana çımaya başladığı fark edilmektedir (9-11). Ancak hem Türkçe kullanımda bu konuda henüz tam bir görüş birliği sağlanamadığı için, hem de makale hazırlanırken farklı içerikteki kaynaklardan yararlanıldığı için bu makalede, hem "yararsız tedavi" hem de "tıbbi yararsılık" terimleri kullanılacaktır.

\section{Yararsız Tedavinin İçeriği ve Alt Grupları}

Kaynaklar incelendiğinde yararsız tedavi ya da tıbbi yararsızlıkla ilgili tek bir tanımın olmadığı, farklı kaynaklarda farklı tanımların yapıldığı görülmektedir. Hatta bazı kaynaklar, tıbbi yararsızlığı alt gruplara ayırarak konuyu açılama yolunu seçmişlerdir.

Amerikan Toraks Derneği, anlamlı bir sağkalımla sonlanma olasılı̆̆ı çok düşük olan (highly unlikely) tedaviyi, tıbbi olarak yararsız (medically futile) olarak tanımlamaktadır (12). Yoğun Bakım Tıbbı Derneği (Society for Critical Care Medicine) ise uygulanan girişimin tıbbi olarak yararsız olduğu kanısına varılmadan önce, hedeflenen amacı yerine getirmede başarısız olunacağından emin olunması koşulunu öne sürmektedir (13).

Aslında, hangi tedavilerin yararsız kabul edildiğiyle ilgili olarak uzun bir liste yapılabilir (14). Örneğin fizyolojik bir etki oluşturmayacak olan tedavi; etkili olması büyük olasılıkla beklenmeyen tedavi; sadece düşük düzeyde, anlamlı olmayan bir sonuç doğuracak olan tedavi; yararlı olmaktan ziyade külfetli olma olasılığı daha yüksek olan tedavi; denenmemiş bir "tedavi" olduğu için tümüyle tartışmalı olan "tedavi"; etkililik, potansiyel yarar ve potansiyel yük hesaplandığında tedaviyi sonlandırma ya da tedaviyi başlatmamayı gerektiren tedavilerin tümü, yararsız tedavi olarak değerlendirilebilir.

Bir yaklaşıma göre, eğer şu üç durum mevcutsa tıbbi yararsızlık gerçekleşmiş olur: 1) Bir hedef vardır, 2) Bu hedefi gerçekleştirmeyi amaçlayan bir eylem ve etkinlik vardır, 3) Bu hedefi gerçekleştirmek için uygulanan eylemin başarısız olacağına dair "görünürde kesinlik" (virtual certainty) vardır (15). Ancak buradaki "görünürde kesinlik" ifadesinin kendisi bir kesinlik içermediği ve muğlak bir ifade olduğu için, bu tanım tartışmalı hale gelmektedir.

Bu konuyu ilk inceleyen yazarlardan olan Schneiderman yaptığı tanımda, deneyime ve niceliğe vurgu yapmaktadır (16): Hekimler (kişisel deneyimleri, iş arkadaşlarıyla ortak deneyimleri ya da yayınlanmış ampirik verileri göz önüne aldıklarında) son 100 olguda tıbbi bir tedavinin yararı olmadı̆gın düşünüyorlarsa, bu tedaviyi yararsız tedavi olarak görmelidirler.

Bazı yazarlar yararsızlığı alt gruplar üzerinden tanımlama yoluna gitmişlerdir. Örneğin Youngner niceliksel, niteliksel ve fizyolojik yararsızlık olarak, kavramı üç başılı altında inceler (17). Fizyolojik yararsızlıkta önemli olan, herhangi bir tedavi ya da teknolojik yöntemin belirli bir hasta için belirli bir amaca ulaşmada etkin olup olmadığıdır. Yani uygulanan tedavinin fizyolojik bir etki oluşturmaması gerekir. Şu durumlar fizyolojik yararsızlığa örnek olarak verilmektedir: Hemodiyalizin renal işlevleri yerine getirememesi, iki saat süreyle 
uygulanan kardiyopulmoner canlandırmanın spontan dolaşımı sağlayamaması ya da maksimum inotropik desteğe karşın son dönem dilate kardiyomyopatili hastada kardiyojenik şokun devam ediyor olması. Yararsız tedavinin niceliksel ve niteliksel yönlerini değerlendirmek ise çok kolay değildir. Çünkü aslında bunlar değer yargılarına bağlıdır ve hastanın ya da yakınının kabul ettiği nicelik ve nitelik ile hekimin gördügü niceliksel ve niteliksel yararsızlık arasında önemli farklar bulunabilir. Yine de bir tanım yapmak gerekirse, eğer bir tedavi hastanın hayatta bulunma amacına/hedefine, tercihlerine, değerlerine uyumlu bir yaşam sürmesine olanak tanımıyorsa, bu durum niteliksel yararsızlık olarak tanımlanabilir. Doğaldır ki bu da ne klinik olarak ne de (yukarıda fizyolojik yararsılık kavramı içinde sözü edilen) son 100 hastadan elde edilen verilerle değerlendirilebilecek bir durum değildir.

Wilkinson ise yararsızlık kavramını beş alt grup alında inceler (18).

Fizyolojik yararsızlık (Fizyolojik hedefe ulaşmayı sağlamayacak olan tedavi)

Niceliksel yararsızlık (Sonuca ulaşma şansı < \%1 olan tedavi)

Niteliksel yararsızlık (Kabul edilebilecek düzeyde bir yaşam kalitesi sağlamayacak olan tedavi; Hastanın sadece bilinç kapalılı̆̆ı durumunu muhafaza eden ya da yoğun bakıma bağımlılığı ortadan kaldıramayan tedavi)

Yakın gelecekte ölüm yararsızlığı (Imminent demise) (Hastanın yakın bir gelecekte öleceği gerçeğini değiştirmeyecek olan tedavi)

Ölümcül durum yararsızlığı (Hastanın mevcut hastalığı, hem sözü edilen tedaviden etkilenmeyecektir, hem de hastayı haftalar ve aylar içinde ölüme götürecektir)

Futility sözcüğünü açıklığa kavuşturmak amacıyla yapılmış olan çok sayıda tanımın bulunması, bu konuda tam bir görüş birliği olmadığını ortaya koymaktadır. Zaten bu konudaki ilklerden birisi olan ve 1999'da Amerikan Tıp Birliği (AMA) tarafından hazırlanmış olan yayında da, yararsız tedavinin tümüyle nesnel ve kesin bir tanımının yapılamayacağı ifade edilmiştir (19). Bu görüş Haziran 2016'da yenilenen Amerikan Tıp Birliği Tıbbi Etik Kodu’nda da aynı şekilde yinelenmiş ve "futile sözcüğünün anlamı, her bir özel klinik durumda her hastanın değerleri ve hedeflerine bağımlıdır” açıklaması yapılmıştır (20). Ayrıca Amerikan Tip Birliği'nin yenilenen bu Kod'unda başlık olarak, medical futility yerine "tıbbi olarak etkisiz girişimler" (medically ineffective interventions) ifadesini tercih ettiği dikkat çekmektedir.

Tüm bunlara karşın pratik kullanım için yararsız tedavinin bir tanımı yapılması gerekirse, şöyle bir tanımlama yapılabilir: "bir hastanın nihai klinik durumunu değiştirme beklentisi çok az olan, hem emek hem de maddi anlamdaki yoğun tıbbi girişimlerdir" (11). Bunun dışında, "sonucu kestirilemeyen, ne kadar yararı olacağı kestirilemeyen ve yarar/külfet oranı beklenenin altında olan işlem ya da tedaviler" de yararsız tedavi olarak tanımlanabilir. Biyoetik Terimleri Sözlüğ̈̈nde ise "hastaların içinde bulunduğu durumu düzeltme olasıllı̆ı olmayan ya da çok düşük olan veya halen uygulanmakta olan tedaviden daha yararlı olması beklenmediği halde daha pahalı ya da daha riskli olan tedaviler", yararsız tedavi olarak adlandırılmaktadır (6).

Beauchamp ve Childress bu konuyu, "Hastaya Zarar Vermeme" bölümünde ve "Görünürde Tedavi Zorunluluğunu Hükümsüz Kılan Durumlar” başlığı altında incelemektedirler (14). Buradaki metne göre bazı durumlar; hastaların, yakınlarının ya da sağlık çalışanlarının, tedaviyi başlatmama ya da tedaviyi sonlandırma kararlarını meşru kılmaktadır. Bu durumlar içinde ilk sırayı "yararsız ya da amaçsız tedavi" (futile or pointless treatment) almaktadır.

İngilizcede yararsız tedaviyi ifade etmek için kullanılan futile treatment ya da medical futility yerine kullanılması önerilen başka ifadeler de bulunmaktadır. Örneğin bazı yazarlar yararsı (futile) sözcüğü yerine "tıbbi olarak uygun olmayan" (medically inappropriate) terimini tercih etmektedirler (21). Bu tercih için ise iki neden öne sürülmektedir. Öncelikle bu deyim, tanımın sağlık çalışanları tarafından tanımlanan değer yargıları olduğuna vurgu yapmaktadır. İkincisi de "uygun olmayan” sözünü kullanmakla, neyin "uygun” olduğunu açık bir 
şekilde tanımlamanın önemi de ortaya konmuş olmaktadır. Bunların yanında, yararı olmayan bir tedaviyi tanımlamak için "klinik yararsızlık" (clinical futility), yararlı olmayan tedavi (non-beneficial treatment), "tıbbi olarak uygun olmayan" (medically inappropriate), "klinik olarak uygun olmayan" (not clinically apppropriate), "tıbbi olarak önerilemez" (medically inadvisable) ve "tıbbi olarak endike olmayan" gibi sözcüklerin de kullanıldığı bildirilmektedir (18).

\section{Tarihçe}

Aslında yararsız tedavi kavramının geçmişi antik dönemlere kadar uzanmaktadır. Hipokrat hekimlerin, hastalıkları çok ilerlemiş kişileri tedavi etmeyi reddetmeleri gerektiğini, çünkü bu tür olgularda tıbbın güçsüz olduğunu ifade etmişsir (22).

Ama bu kavram tıp literatüründe ve etik literatürde, son 30-40 yılda tartışılmaya başlanmıştır. Bu açıdan 1990'da Annals of Internal Medicine dergisinde "tıbbi yararsızlık" kriterlerinin yayınlanması önemli bir aşamadır (16). Ancak böyle önemli bir adım atılmasına karşın bu tarihten tam on yıl sonra, bu konuya ilginin azaldığının ve umutların kıııldığının ifade edildiğine dair başka bir makalenin yayınlanmış olduğu göze çarpmaktadır (23). Çünkü bu on yıllık süre içinde gerçekleştirilen çalışmalara ve yapılan tartışmalara karşın, ne nafileliğin tanımı konusunda ne de konulmaya çalışılan kriterler konusunda bir fikir birliğine varılması mümkün olmamışır. Tabii ki bunda, konunun tek bir boyutunun olmayıp tıbbi, etik, dini ve yasal boyutlarının bulunması da rol oynamış olabilir.

\section{Yararsız Tedavi Kararında Etik Temellendirme}

Hastanın değerlendirilmesi sonucunda, eğer tedavinin yararsız olduğu kararı verilirse ne yapılması gerektiği sorusu, önemli bir sorun olarak karşımızda durmaktadır. Böyle bir durumda aile karşı çıksa bile yaşamı destekleyici tedaviler sonlandırılmalı mıdır, yoksa hastaya acı ve ıstırap çektireceği bilinse de mevcut tedaviye devam mı edilmelidir?

Hastanın/ailenin tedavinin devamını istemesine karşın hekim tedavi uygulamayı reddediyorsa, bu karar için şu etik temellendirmeler kullanılabilir (18):

1-Hekim, tedavinin hastanın çıkarlarına aykırı olduğunu ve hastanın bu tedaviden zarar görebileceğini düşünmektedir. Bu olası zararın kapsamı içinde de, yaşam süresinin kısalması, yaşam kalitesinin azalması, tedavinin ağrı ya da distrese neden olması gibi gerekçeler bulunabilir. Bu tür yaklaşım, tipik bir paternalistik bakış açısını yansıtmaktadır.

2-Sözü edilen tedavinin uygulanması, dolaylı olarak diğer hastalara zarar verebilir. Bu tür yaklaşım ise, kısıtlı kaynakların adil kullanımı bağlamında ortaya atılan bir etik temellendirmedir.

Diğer taraftan hastanın/ailenin talebini kabul etmek de, her zaman için uygun bir tutum olarak kabul edilmeyebilir. Bunun nedenleri arasında, ailelerin gerçekçi olmayan beklentiler içinde bulunabilecekleri, mucizevi sonuçların ortaya çıkmasını bekleyebilecekleri ya da tıbbi verileri yanlış yorumlayabilecekleri ileri sürülebilir (11).

Hasta yakınlarının bu şekilde davranmasında, medyanın da önemli bir etkisinin olduğu söylenebilir. Konuyla ilgili olarak yapılmış bir çalışma, hayli ilginç sonuçlar vermiştir. Bu çalışmada, televizyonda gösterilen tıbbi dizilerdeki kardiyopulmoner canlandırma (KPC) başarıları ile bilimsel yayınlardaki KPC başarıları karşılaştırılmışııı (24). Sonuçlara göre gerçek hayatta KPC başarı oranı \%10-15'den fazla değilken, dizilerdeki KPC girişimine hemen yanıt verip hayata dönme oranı $\% 75$, hastaneden taburcu olma oranı da \%67 olarak saptanmışır (24). Dolayısıyla, bilimsel gerçeklerden epeyce uzak olan bu tür bilgiler, hasta yakınlarının bilgi ve beklenti düzeylerini de olumsuz yönde etkilemektedir. 


\section{Farklı Hasta Gruplarında Yararsız Tedavi}

Bazı özel hasta gruplarında bu uygulamalara daha fazla özen gösterilmesi ve olguların daha dikkatli incelenmesi gerekmektedir (11). Çocuklar, özürlüler, yaşlılar, sosyoekonomik durumu düşük ya da sağllk güvencesi yetersiz hastalar, bu özel hasta grupları içinde sayılabilir (11). Bunun dışında yoğun bakım hastaları ve yenidoğanlar da daha fazla özen gösterilmesi gereken grup içinde değerlendirilebilir.

\section{Yararsız Tedavi İçin Veri Elde Etmeye Yönelik Çalışmalar}

Hollandảda yapılan bir çalışmada, ağır nörolojik hasar nedeniyle mekanik ventilasyon desteği alan hastaların bir yıllık takip sonuçları incelenmiş ve mortalite yüksek olmasına karşın bu hastaların bir yıllık sağkalım oranlarının \%22 olduğu saptanmıştır. Dolayısıyla araştırmacılar, mekanik ventilasyon desteği altındaki hastaların, tıbbi yararsızlık kapsamı içinde değerlendirilmemesi gerektiği sonucuna varmışlardır (25).

Avusturya, İsviçre ve Almanya'da yapılan bir çalışmada ise hastane dışı kardiyak arrest olguları incelenmiş, ne sağkalım açısından ne de hastaneye gereksiz transferi elimine etmek açısından, herhangi bir etken ya da etken kombinasyonunun anlamlı bir etken olmadığı saptanmıştır (26).

Amerika Birleşik Devletleri'nde yapılmış olan ve hekimlerin, hastaların akıbetini belirleme yeteneklerini araşııran bir çalışma, bu konuyla ilgili olumlu bir örnek sayılabilir. Çalışmanın sonuçlarına göre Beyin Cerrahisi yoğun bakım hekimleri, yoğun bakım biriminde 72 saatten fazla kalan hastalardaki kötü akıbeti, iyi akıbetten daha isabetli bir şekilde öngörebilmektedirler (27).

Tüm bu çalışmalar, farklı hasta gruplarında yararsız tedaviyle ilgili ölçütlerin belirlenmesi yolunda önemli veriler sağlamaktadır.

\section{Türkiye'deki Durum}

Yararsız tedavi konusunda yazılmış yurtdışı kaynaklı birçok metinde, hekimlerin yararsız bir tedaviyi uygulamak için etik zorunlulukları bulunmadığına vurgu yapılmaktadır (28). Ülkemizde bu konuda yasal bir düzenleme bulunmamakla birlikte, meslek örgütleri tarafından yayınlanmış olan metinlerde bu görüşü destekleyen ifadelere yer verildiği görülmektedir.

Bazı kaynaklar, Hekimlik Meslek Etiği Kuralları’nın 30. maddesini yararsız tedavi konusundaki düzenlemelere örnek olarak göstermektedirler. Türk Tabipleri Birliği (TTB) tarafından 1999'da yayınlanan ve 2015'de güncellenen Hekimlik Meslek Etiği Kuralları'nın 30. maddesinde "Hekim ... hastaya ... yararı olmayacağını bildiği bir tedaviyi veremez" denmektedir (29). Ancak bu maddenin yararsız tedavi kapsamında değerlendirilmesi çok doğru görünmemektedir. Çünkü hem bu cümlenin öncesinde "Hekim, hastasının parasal durumu ne olursa olsun, kesin zorunluluk olmadıkça pahalı ilaçlar ve yöntemler öneremez, hastaya gereksiz harcamalar yaptıramaz" denmektedir, hem de bu madde, "Gereksiz Harcama Yaptırma Yasağı” başlığı alıında yer almaktadır. Dolayısıyla bu madde bu şekliyle, doğrudan yararsız tedaviye atıf yapan bir ifade değildir.

Yararsız tedavi konusu, hem TTB’nin 2008 tarihinde yayınladığı Etik Bildirgeler Çalıştayı Sonuç Raporları’nda (30), hem de bunun güncellenmiş hali olan 2010 tarihli TTB Etik Bildirgeleri'nde işlenmiştir (31). Bu metinlerden olan 2010 tarihli Yaşamın Sonuna İlişkin Etik Bildirge’nin konuyla ilgili bölümleri şu şekildedir (31):

\section{Yaşamı Destekleyen Tedavilerin Sonlandırılması ya da Tedaviye Başlanmaması}

1. Tibbi yararsızlı söz konusu olduğunda ventilatör desteği hastadan esirgenebilir ya da sonlandirlabilir, 
2. Hastanın ăgrı, acı çekme süresinin uzamasına, beklenen ölümün ertelenmesine yol açan yapay beslenmel sıvı desteği sonlandırılabilir,

3. Hastanın yaşam niteliği çok düşük ise ve yaşam desteği să̆landığında yaşam nitelĭği iyileştirilemeyecekse hasta canlandirlmayabilir,

4. Kronik hastalğğnın seyrinde hastaya yaşam desteği sağlanması öngörülüyorsa, hastanın asıl hekimi hastanın yaşam desteği konusunda görü̈s̈̈nü sorgulamalı ve karar verme yeterliliğini yitirdiği olası durumlar için isteğini açıklamasını önermelidir,

5. Bu tür bir hasta iradesi bulunmadiğ̊ durumda hastanın vekiline yaşamı destekleyen tedavilerin hastaya olan yararı ayrıntılarıyla açıklanmalı ve kararları sorgulanmalıdır,

6. Özellikle yoğun bakım çalş̧anlarının yaşayabileceği etik ikilemlerle baş etmelerine yardımcı olacak "yaşamı destekleyen tedavilerin başlanması ya da sonlandırılmasına ilişkin ulusal ölçütler" belirlenmelidir,

7. Ulusal tıbbi ölçütler hazırlanırken, yaşamı destekleyen tedavilerle elde edilecek olan tıbbi yarar sadece hasta yönünde değil, toplum yönünde de gözetilmelidir

\section{Yararsız (Boşuna) Tedavi}

Hastaya önerilen ya da durumu için mümkün olabilen tedavinin yararsız ya da etkisiz olduğu, yaşamın niteliğine

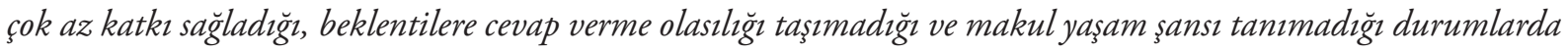
tedavi ya da uygulama tıbbi açıdan yararsız olarak değerlendirilmektedir

Özellikle terminal dönemde agresif yaşam destek tedavilerinin hastaya durumunu düzeltme şansı tanımadĭğ ve fizyolojik bir yarar sağlamadı̆̆̆, aksine ilave ă̆rı, acı çekmesine ya da sıkıntı çekme süresinin uzamasina neden olduğu durumda öngörülen tedavinin yapılmaması etik açıdan savunulabilirdir

Hastaya önerilecek her tıbbi uygulamanın hastaya getirebileceği yarar, verebileceği zarar ve riskler dikkate alınmal, elde edilecek tıbbi yarar ile katlanılacak külfet tartılmal, en azından dengelenmelidir

Ayrıca, TTB tarafından 2009'da yayınlanan Sağlıkla İlgili Uluslararası Belgeler içerisinde yer alan bir bildirgede, yararsız tedavi konusu da kendine yer bulmuştur (32). Dünya Tabipler Birliği'nin 1983'de benimsediği, Ölümle Sonuçlanacak Hastalık'la ilgili Venedik Bildirgesi'nde konu şu şekilde yer almaktadır (32):

Hekim, ölümcül hastalı̆̆ın son dönemindeki bir hastada hastanın rızası, -hasta kendi isteğini açıklayamıyorsa en yakın akrabasının karar- ile tedaviyi keserek hastanın acısın dindirebilir.

Hekim tedaviyi kesme gerekçesiyle, ölmekte olan kiş̧iye yardım etme ve onu hastalĭğnın son döneminde rahatlatmak için gerekli ilaçları verme sorumluluğundan kurtulamaz.

Hekim hastaya herhangi bir yarar sağlamayacak olan ve olağan olmayan yöntemler uygulamaktan kaçınmalıdır.

\section{Yararsız Tedavi Politikası Oluşturmak Gerekli midir?}

Uygulamada yararsız tedavi konusunda taraflar arasında görüş ayrılıklarına sıkça rastlandığı için, bu tür sorunların çözümü büyük önem taşımaktadır. Görüş ayrılıkları ortadan kaldırılıp sorun çözüme kavuşturulabilirse, olayın daha ileri boyutlara taşınması ve yeni tıbbi, sosyal, finansal ve hukuki sorunlara neden olması da önlenebilecektir. Bu açıdan hekimlerin, sağlık kurumlarının, idari ve yasal mercilerin gösterecekleri çabalar ve yapacakları girişimler, bu alana katkı sağlayacaktır.

Yararsız tedavi ile ilgili sorunların çözümü için önerilen iki temel yaklaşım vardır (18). İlk yaklaşımda, tedaviyi sonlandırma ya da tedaviyi başlatmama için gereken ölçütler oluşturulmaya çalışılmaktadır. Örneğin ABD’nin Tennessee eyaletindeki Tek Taraflı Sağlık Bakım Kararları Yasası gibi düzenlemeler bunun bir örneğidir (33). 
İkinci yaklaşımda ise ölçüt oluşturmak yerine, ortaya çıkan sorunların çözümüne yönelik süreçlerle ilgili çalışmalar yapılmaktadır. ABD'nin Texas eyaletinin yetkilendirme bildirimi ile ilgili kanunu da bunun bir örneğidir (34). Bu kanunun 2002'de yürürlüğe girmesinden sonraki uygulama sonuçlarına yönelik yapılan bir araştırma, bu tür düzenlemelerin yararlı olabileceğini göstermektedir (34).

Yaşamın sonuna doğru alınan kararlar konusuyla ilgili konularda, yurtdışındaki mahkemeler kendilerini bu konulardan uzak tutmayı tercih etmişler, bu durum da hastane etik kurulları gibi kurumların gelişmesini teşvik etmiştir (35). Bu nedenle artık bu tür sorunlar, genellikle taraflar arasındaki etkili bir iletişim yoluyla çözüme kavuşturulmakta, çözümsüzlük durumunda da konu etik kurulların önüne gitmektedir. Önerilen başka bir ara yöntem ise mahkeme aşaması gidilmeden önce sorunun arabuluculuk kurumu eliyle çözüme kavuşturulmasını sağlamaktır (11).

Gerçi bu iki yöntemin de, yani gerek yararsız tedavi için ölçütler oluşturmaya çalışmanın, gerekse de ortaya çıkan anlaşmazlıkları çözmeye yönelik çalışmalar yapmanın yararsız tedavi sorununu tümüyle ortadan kaldırdığını söylemek mümkün değildir. Çünkü ABD’nin birçok eyaletinde buna yönelik yasal düzenlemeler bulunmakla birlikte, bunların genelde etkisiz kaldığı belirtilmektedir. 1990’ların sonunda ABD'de yapılan bir araştırmaya göre, Amerikan hastanelerinin çoğunluğunda bu tür bir politika oluşturulmuş değildir (36). Zaten bu politikalar oluşturulmuş olsa bile bunlar nadiren uygulamaya geçirilmekte ve aile talep ettiği süre boyunca tedaviye devam edilmektedir (33). Bunun dışında, yararsız tedavinin tanımıyla ilgili belirsizliklerin, hekimlere ve kurumlara yasal bir koruma sağlayamaması da bu konunun önündeki yasal boyuttaki sorunlardan birisidir (33).

Yararsız tedavi konusu tartışılırken olayın finansal boyutunun da göz ardı edilmemesi gerektiği açıktır. Çünkü yararsız tedaviler, kamuya ağır bir maliyete neden olabilmektedirler (11). Bu konuda bir rakam vermek gerekirse,

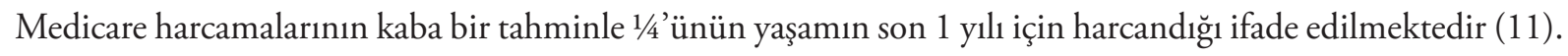

\section{Yararsız Tedavi Politikası Oluştururken Nelere Dikkat Edilmeli?}

Genel olarak kabul edilen görüşe göre sağlık kurumları, yararsız tedavi konusunda önceden belirlenmiş politikalara sahip olmalıdırlar. Buna bağlı olarak da, politika oluştururken göz önünde tutulması gereken noktaların neler olduğu önem kazanmaktadır. Amerikan Kadın Hastalığı ve Doğum Uzmanları Birliği, politika oluştururken göz önüne alınması gereken noktalar konusunda bir öneriler listesi yayınlamıştır. Bu listede yer alan öneriler şu şekildedir (37):

- Taraflar arasındaki iletişimi artırmak amaçlanmalıdır

- Hasta ile hekim ve diğer sağlık personeli arasında bir uzlaşma oluşturmaya yardımcı olmak için sorumlu hekim, (hemşire, sosyal hizmet uzmanı gibi) tedavi ekibinin tüm üyelerini sürece dahil olmaya teşvik edilmelidir

- Konuyla bağlantılı olabilecek tıp alanlarında ya da tıbbi etik alanında uzman diğer kişi ya da gruplarından da veri elde edebilecek şekilde oluşturulmalıdır

- Bir anlaşmazlık durumunda sorunu çözüme kavuşturabilmek için, etik danışmanlık ya da etik kurul gibi kurumsal mekanizmaları içermelidir

- Hastaya, bakış açısı kendisininkiyle daha uyumlu olan başka bir hekim seçme olanağı tanımalı, tedaviyi ilk üstlenen hekimin önyargısız bir şekilde hastanın naklini kolaylaştırmasını sağlamalıdır

- Hastanın bakımı için başka bir birime nakledilmesi kararı verildiyse, naklin beklendiği dönemde mevcut devam eden tüm yaşamı destekleyici tedavi ve girişimlere devam edilmelidir 
- Taraflar arasında görüş birliği sağlanmamış ya da hastanın nakli gerçekleşmemişse ya da başka bir hekim ya da kurum istenen tedaviyi sağlamaya razı olmamıssa, mevcut hekimin tıbbi olarak yararsız gördüğü tedaviyi sürdürmesi gerekmez

- Hekimin eyleme geçme zamanı yaklaşıyorsa ya da hasta yakınlarının hala karara itirazları varsa, hasta yakınlarının başvurabileceği temyiz türü bazı süreçler olmalıdır

- Hekimler yararsız bir girişimi uygulamayı reddettiklerinde ya da tedavinin herhangi bir parçasını uygulamayı bıraktıklarında, sağlıkla ilgili bakım hizmeti sunma zorunlulukları azalmış sayılmaz. Hastanın konforunu sağlayıcı bakımı sağlamak, palyatif bakım sağlamak ve yaşam kalitesini en üst düzeyde tutmak, hekimin temel yükümlülükleri arasındadır

- Bu politikada şu tür bilgileri içeren bir belgelendirme de olmalıdır: olası tanılar, olası prognoz, hekimin önerdiği alternatifler, hastanın istediği süreç, izlenmiş olan karar verme süreci

\section{Örnek Politikalar}

Amerikan Tıp Birliği Etik ve Hukuk Kurulu tarafından hazırlanan politika, bu alandaki örnek bir metin olarak görülebilir (19). Yedi basamaklı bu politika örneği, şöyle özetlenebilir:

1- Konuyu tartışmanın ve müzakere etmenin öncesinde, hekim ile hasta veya hasta vekili arasında hasta için yararsız tedavinin ne olduğu ve hekim, aile ve belki de kurum açısından kabul edilebilir sınırların ne olduğu konusunun anlaşılması için ciddi girişimler yapılmalıdır.

2- Hasta/hasta vekili ile hekim arasında mümkün olan en üst derecede bir ortak karar alma süreci yaratılmalıdır.

3- Anlaşmazlık durumunda bunu müzakere etmek ve tüm tarafların kabul edebileceği sınırlar içinde bir çözüme kavuşturmak için girişimlerde bulunulmalıdır. Bunun için eğer uygunsa etik danışmanların da yardımı alınmalıdır.

4- Eğer anlaşmazlıklar çözülemeyecek durumdaysa etik kurullar gibi kurumsal kurullar sürece dahil edilmelidir.

5- Eğer bu yapılar hastanın kararını destekleyip hekim için ikna edici olmazsa, hastanın kurum içinde başka bir hekime devri planlanabilir.

6- Eğer bu süreçte hekimin kararının uygun olduğu belirtilmesine karşın, bu karar hasta/hasta vekili için ikna edici olmazsa, hastanın başka bir kuruma nakli düşünülebilir. Ancak böyle bir durumda hem hastayı nakleden hem de hastayı nakil alan kurumların her ikisi de durumu uygun bulmuş olmalıdır.

7- Eğer hastanın nakli mümkün değilse, bahse konu olan tedavi ya da girişimin uygulanmasına gerek yoktur.

ABD'nin Texas eyaletinin Yetkilendirme Bildirimi Yasası da, Amerikan Tip Birliği önerileri gibi sorunu yargı aşamasına gelmeden önce çözme yolunda adımlar içerir (38). Burada hekimin yararsız tedavi olarak değerlendirdiği durumu öncelikle etik kurul inceler. Eğer etik kurul hekimin kararını uygun görürse nakile kadar geçen dönemde hekim tedaviyi on sün süreyle devam ettirmek zorundadır. Hasta ya da hasta yakınları sürenin uzamasını istiyorlarsa mahkemeye başvurabilirler. Hekimlere hastanın isteğini reddetme izninin verildiği $A B D$ 'nin birçok eyaletinde, hekimler ve kurumların, hastayı nakledene kadar tedaviye devam etme zorunluluğu bulunmaktadır (39). Aynı durumun söz konusu olduğu Avustralya, Kanada ve Birleşik Krallık’ta da hekimlerin yararsız tedavi uygulamaya zorunlu olmadıkları ama hastanın nakline kadar yaşamı sürdürücü (life-sustaining) tedaviye devam etmelerinin gerekli olduğu bildirilmektedir (39). 
Ancak uygulamada başka sorunların da ortaya çıkmasına engel olmak için, sadece bu tür bir politika oluşturmak yeterli olmamaktadır. Hastanın ya da hasta vekillerinin de bu politikalardan haberdar edilmesi mutlak bir zorunluluk olarak görülmektedir.

\section{Sonuç}

Yararsız tedavi ya da tıbbi yararsızlık, başta yoğun bakım ve terminal dönem malignite hastaları olmak üzere çok farklı hasta gruplarını ilgilendiren önemli bir konudur. Böyle bir durumda ortaya çıkabilecek sosyal, idari ve yasal sorunların önlenmesi açısından, önceden kurumsal politikaların oluşturulması büyük önem taşımaktadır. Etik danışmanların ve etik kurullarının da bu tür kurumsal politika süreçlerine dahil edilmesi, sorunun çözümüne önemli katkılar sağlayabilecek bir zorunluluk olarak görülmelidir.

\section{KAYNAKLAR}

1. http://www.merriam-webster.com/dictionary/futile Erişim tarihi 17.08.2016.

2. Ersoy N. Etiğe uygun kanser bakım sistemi. Hacettepe Tıp Dergisi 2009:40(2):102-107.

3. Akpınar A, Ersoy N. Yaşamı destekleyen tedaviler: Ne zaman esirgenmeli? Ne zaman sonlandırılmalı? Türk Onkoloji Dergisi 2012:27(1):37-45.

4. Özden D, Karagözoğlu Ş, Yıldırım G, Tabak E. Yoğun bakım çalışanlarının nafile tedaviye ilişkin görüşleri. Hemşirelikte Araştırma Geliştirme Dergisi 2013:15(2):42-55.

5. Özaltay B. Beyhude tedavi. SD Dergi 2010:14. http://www.sdplatform.com/Dergi/380/Beyhudetedavi.aspx Erişim tarihi: 05.06.2016.

6. Oğuz YN, Tepe H, Örnek Büken N, Kırımsoy Kucur D. Biyoetik terimleri sözlüğü. Ankara: Türkiye Felsefe Kurumu; 2005.

7. Özışık L, Topeli A. Yoğun bakımda yaşam sonu kararları. In: Örnek Büken N, Akpınar A, editörler. Klinik, etik, kültürel ve hukuki yönleriyle yaşamın sonuna ilişkin kararlar toplantısı. Hacettepe Üniversitesi Biyoetik Eğitim Uygulama ve Araştırma Merkezi (HÜBAM). Ankara: Hacettepe Üniversitesi Matbaası, 2014.

8. Özden D, Karagözoğlu Ş, Tel H, Tabak E. Yoğun bakım ünitesinde çalışan hemşirelerin yararsız tedavi ve uygulamaya ilişkin görüşleri. Hemşirelikte Araştırma Geliştirme Dergisi 2012:14(1):1-10.

9. Schneiderman LJ. Defining medical futility and improving medical care. Bioethical Inquiry 2011:8(2):123-131.

10. Rubin E, Courtwright A. Medical futility procedures: What more do we need to know? Chest 2013:144(5):1707-1711.

11. Swetz KM, Burkle CM, Berge KH, Lanier WL. Ten common questions (and their answers) on medical futility. Mayo Clin Proc 2014:89(7):943-959.

12. American Thoracic Society. Withholding and withdrawing life-sustaining therapy. Ann Intern Med 1991:115(6):478-485.

13. The Ethics Committee of the Society of Critical Care Medicine. Consensus statement of the SCCM's Ethics Committee regarding futile and other possible inadvisable treatments. Crit Care Med 1997:25(5):887-891.

14. Beauchamp TL, Childress JF. Principles of biomedical ethics. 7th edition. New York: Oxford University Press; 2013.

15. Trotter G. Mediating disputes about medical futility. Camb Q Health Ethics 1999:8(4):527-37.

16. Schneiderman LJ, Jecker NS, Jonsen AR. Medical futility: its meaning and ethical implications. Ann Intern Med 1990:112(12):949-954. 
17. Youngner SJ. Who defines futility? JAMA 1988;260(14):2094-2095.

18. Wilkinson DJC, Savulescu J. Knowing when to stop: Futility in the intensive care unit. Curr Opin Anaesthesiol 2011:24(2):160-165.

19. Council on Ethical and Judicial Affairs, American Medical Association. Medical futility in end-of-life care. Report of the Council on Ethical and Judicial Affairs. JAMA 1999:281(10):937-941.

20. AMA Code of Medical Ethics. http://www.ama-assn.org/ama/pub/physician-resources/medical-ethics/ code-medical-ethics.page Erişim tarihi: 11.09.2016

21. Wilkinson D. The self-fulfilling prophecy in intensive care. Theor Med Bioeth 2009:30(6): 401-410.

22. The Loeb Classical Library. Hippocrates. Vol II. Goold GB, editor. Jones WHS, translator. Cambridge Mass: Harvard University Press; 1995.

23. Helft PR, Siegler M, Lantos J. The rise and fall of the futility movement. N Engl J Med 2000:343(4):293296.

24. Diem SJ, Lantos JD, Tulsky JA. Cardiopulmonary resuscitation on television. Miracles and misinformation. N Engl J Med 1996:334(24):1578-1582.

25. van Gestel JP, Robroch AH, Bollen CW, et al. Mechanical ventilation for respiratory failure in children with severe neurological impairment: is it futile medical treatment? Dev Med Child Neurol 2010:52(5):483-488.

26. Pircher IR, Stadlbauer KH, Severing AC, et al. A prediction model for out-of hospital cardiopulmonary resuscitation. Anesth Analg 2009:109(4):1196-1201.

27. Finley Caulfield A, Gabler L, Lansberg MG, et al. Outcome prediction in mechanically ventilated neurologic patients by junior neurointensivists. Neurology 2010:74(14):1096-1101.

28. Feltman D, Stokes T, Kett J, Lantos JD. Is treatment futile for an extremely premature infant with giant omphalocele? Pediatrics 2014:133(1):123-128.

29. Hekimlik Meslek Etiği Kuralları. Yayın Tarihi: 01.02.1999. Son Güncelleme 26.08.2015. http://www. ttb.org.tr $/$ mevzuat $/$ index.php?option=com_content\&id=65\&Itemid=31 Erişim tarihi: 15.05.2016.

30. Türk Tabipleri Birliği Etik Bildirgeler Çalıştayı Sonuç Raporları. Birinci Baskı, Haziran 2008, Ankara, Türk Tabipleri Birliği Yayınları.

31. Türk Tabipleri Birliği Etik Bildirgeleri. Türk Tabipleri Birliği Etik Kurulu. Birinci Baskı, Mayıs 2010, Ankara, Türk Tabipleri Birliği Yayınları.

32. Sağlıkla İlgili Uluslararası Belgeler. Dünya Tabipler Birliği, Avrupa Konseyi, Birleşmiş Milletler, Unesco, Avrupa Tabip Birlikleri Forumu. Birinci Baskı, Haziran 1998, Ankara, İkinci Baskı, Ekim 2009, Ankara, Türk Tabipleri Birliği Yayınları.

33. Pope TM. Medical futility statutes: no safe harbor to unilaterally refuse life-sustaining treatment. Tennessee Law Review 2007:75(1):1-81.

34. Fine RL. Point: The Texas advance directives act effectively and ethically resolves disputes about medical futility. Chest 2009:136(4):963-967.

35. Pope TM. Legal briefing: medical futility and assisted suicide. J Clin Ethics 2009:20(3):274-286.

36. Johnson SH, Gibbons VP, Goldner JA, et al. Legal and institutional policy responses to medical futility. J Health Hosp Law 1997:30(1):21-36.

37. ACOG Committee Opinion No. 362. Medical Futility. Committee on Ethics, American College of Obstetricians and Gynecologists et al. Obstet Gynecol 2007. http://www.acog.org/Resources-AndPublications/Committee-Opinions/Committee-on-Ethics/Medical-Futility Erişim tarihi: 13.05.2016.

38. Advance Directives Act. Tex. Health and Safety. http:/www.statutes.legis.state.tx.us/Docs/HS/htm/ HS.166.htm Erişim tarihi: 11.05.2016. 
Türkiye Biyoetik Dergisi, 2016

Vol. 3, No. 2, 74-84

39. McCabe MS, Storm C. When doctors and patients disagree about medical futility. J Oncol Pract 2008:4(4):207-209. 